This item was submitted to Loughborough's Research Repository by the author.

Items in Figshare are protected by copyright, with all rights reserved, unless otherwise indicated.

\title{
Heteronormativity and/as violence: the "sexing" of Gwen Araujo
}

PLEASE CITE THE PUBLISHED VERSION

http://dx.doi.org/10.1111/hypa.12015

PUBLISHER

John Wiley and Sons (@ Hypatia)

VERSION

AM (Accepted Manuscript)

LICENCE

CC BY-NC-ND 4.0

REPOSITORY RECORD

Lloyd, Moya S.. 2019. "Heteronormativity And/as Violence: The "sexing" of Gwen Araujo". figshare. https://hdl.handle.net/2134/15590. 
This item was submitted to Loughborough's Institutional Repository (https://dspace.lboro.ac.uk/) by the author and is made available under the following Creative Commons Licence conditions.

\section{creative
commons}

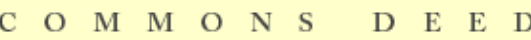

Attribution-NonCommercial-NoDerivs 2.5

You are free:

- to copy, distribute, display, and perform the work

Under the following conditions:

Attribution. You must attribute the work in the manner specified b the author or licensor.

Noncommercial. You may not use this work for commercial purposes.

No Derivative Works. You may not alter, transform, or build upon this work.

- For any reuse or distribution, you must make clear to others the license terms of this work.

- Any of these conditions can be waived if you get permission from the copyright holder.

Your fair use and other rights are in no way affected by the above.

This is a human-readable summary of the Leqal Code (the full license).

\section{Disclaimer 만}

For the full text of this licence, please go to: http://creativecommons.org/licenses/by-nc-nd/2.5/ 


\section{Heteronormativity and/as Violence: The "Sexing” of Gwen}

\section{Araujo}

\section{MOYA LLOYD}

This paper will examine the violence of heteronormativity: the violence that constitutes and regulates bodies according to normative notions of sex, gender, and sexuality. This violence, I will argue, requires more than a focus on gendered or sexualized physical harms of the kinds normally examined when studying violence against sexual minorities or women. Rather, it necessitates focusing on the multiple modalities through which heteronormativity performs its violence on, through, and against bodies and persons, including through the production of certain bodies and persons as inciting violence in their very being. To establish my argument, I explore the killing in 2002 of trans woman Gwen Araujo and the violence of the legal strategy (the trans panic defense) used in the legal trials that followed her killing. Both forms of violence, I suggest, operate in a similar way, albeit through different mechanisms, to maintain and extend the system of binary morphology that itself entails the perpetual violent materialization of sexed bodies.

On October 3, 2002, seventeen-year-old Gwen Araujo was killed at a party in Newark, California by four men, who "kneed her in the face, slapped, kicked, and choked her, beat her with a can and a metal skillet, wrestled her to the ground, tied her wrists and ankles, strangled her with a rope, and hit her over the head with a shovel." They then "buried her in a shallow grave and went to McDonald's for breakfast” (Steinberg 2005, 499-500). The precipitating cause for this violent assault on Araujo, who had lived and identified as a woman from age 14, was the coerced revelation that she had male genitalia. (Araujo was held down in the bathroom by her assailants who forcibly removed her underwear.) $<1>$ 
Araujo was neither the first, nor indeed is she likely to be the last, transgender individual to die so violently. According to figures provided on the Transgender Day of Remembrance website, between March 1970 and October 2010 more than 300 transgender persons in the US suffered a similar fate. The site also publishes causes of death; this makes for grim reading. The list includes, among other equally horrific things: "Beat (sic) and sexually mutilated by members of a local street gang”; “42 stab wounds to the head, neck, face, and arm”; “Tortured for several hours, beaten to death, and beheaded”; “Stabbed repeatedly and castrated"; "Shot”; "Raped, hit in the head, and drowned"; and "Beaten with beer bottles, sexually assaulted with a broom handle, strangled with an electrical cord and then drowned in a bathtub. His body was later set on fire in a trash can behind a church” (St. Pierre 2011). Extrapolating from data such as this, the Human Rights Commission has estimated that "one out of every 1,000 homicides in the U.S. is an anti-transgender hate crime” (Human Rights Commission 2011). The preliminary findings of a study organized by Transgender Europe, The Trans Murder Monitoring Project, indicate that worldwide "since the beginning of 2008 the murder of a trans person is reported every third day, on average” (Balzer 2009, 148).

It is not, specifically, the level of brutality involved in trans murder that interests me in this paper, though clearly it is significant. As the Organization for Security and Cooperation in Europe (OSCE) report for 2007 makes clear, “Homophobic hate crimes and incidents often show a high degree of cruelty and brutality” (OSCE 2007, 53-54, my emphasis; see also Balzer 2009, 149), with trans homicide and assault, in particular, likely to exhibit the characteristics of "overkill": the infliction of injuries in excess of those necessary to cause an individual's death.

The development in particular jurisdictions of hate crime enhancements or laws to prosecute the types of offenses committed against trans persons would appear to suggest that there has been some degree of official recognition of the seriousness of such acts. Yet trans 
murder is often not reported in the media, and many killers of trans individuals are never prosecuted. I am interested in what happens to those who are and, in particular, to those where the defense, with varying degrees of success, has attempted to have trans homicide reduced from murder to manslaughter through the deployment of an exculpatory legal strategy known as the "trans panic" defense.

Although the trans panic defense failed in the case I focus on-the prosecution of Gwen Araujo’s killers-it has succeeded elsewhere. $<2>$ It was the Araujo case, however, that has been credited with bringing the trans panic defense to "national consciousness" (Brigham 2006). $<3>$ For my purposes, it is the "archive" of material available in this case that makes it so significant, for this material provides invaluable insight into what I will call the "heteronormative violence" at work in the construction of a trans panic defense and, in particular, in its deployment of gender norms. $<4>$

Accounts of gendered or sexual violence focus attention mainly on diverse forms of physical brutality, comprising rape, sexual abuse, domestic violence, “queer-bashing,” "gaybashing,” and sexual assault. Here we might legitimately include the fatal assault on Araujo. When victims are gay or trans individuals, this violence is often categorized as either homophobic or transphobic respectively. Against this, I intend to characterize such species of violence as modes of heteronormative violence, that is, violence that constitutes and regulates bodies according to normative notions of sex, gender, and sexuality. $<5>$

To account fully for the violence that is heteronormativity, however, it is necessary, I will argue, to focus not only on gendered and sexualized physical harms of the kinds just listed, whether threatened or actual, though these certainly need to be attended to since the ability to recognize certain acts as "gendered" or "sexualized" violence is central to their prosecution and prevention. Attention must also be paid, however, to the multiple modalities through which heteronormativity performs its violence on, through, and against bodies and persons. 
This includes but is not limited to the violence of gender norms; the way those norms work to position certain bodies and persons outside the realm of "recognizable" violence; and, in this particular context, the kind of violence at stake in the use of the trans panic defense.

The paper thus begins with a brief contextualization of the trans panic defense. This is followed by an explanation of what is meant by heteronormative violence, drawing from work on heteronormativity as well as from the writings of Judith Butler and Michel Foucault. Examining reports of the trial of Araujo's killers as well as legal documents pertaining to the case, I then demonstrate the specific ways that heteronormative violence was enacted.

\section{THE TRIAL}

The prosecution of Araujo's killers was a complicated affair, involving two trials: the first ended in June 2004 when, after ten days of deliberations, the jury was unable to agree on a unanimous verdict. $<6>$ Alameda County Superior Court Judge Harry Sheppard thus declared a mistrial (DeFao and St. John 2004). The second trial took place in September 2005. Initially, all four men involved in her killing (Jason Cazares, Michael Magidson, Jose Merel, and Jaron Nabors) were charged with first-degree murder with a hate crime enhancement, a crime carrying a sentence of twenty-five years to life with little prospect of parole. One of the four defendants, Nabors, however, pleaded guilty to voluntary manslaughter in return for testifying against his three friends; for this he received an eleven-year jail sentence.

As a result of the second trial, Magidson and Merel were both convicted of second-degree murder, with a sentence of fifteen years to life. The jury, however, was not willing to add hate crime enhancements to their convictions. Neither trial was able to determine the fate of Cazares, who denied involvement in Araujo's actual murder, claiming only to have assisted with her burial. He was eventually given a six-year prison term, after agreeing to a plea of “no contest to voluntary manslaughter” (Baldman 2006). 
At the preliminary hearing, lawyers for the defense attempted to have the charges against their clients downgraded from murder to manslaughter (Haddock 2004). They pursued a similar strategy at the two trials that followed. This strategy centered on attempting to persuade the jury that Araujo's slaying was not murder but rather “manslaughter in the heat of passion” (Thorman [defense lawyer], cited in Haddock 2004). The defense thus took the form of what has come to be known as the "trans panic defense," an exculpatory legal strategy designed to absolve killers of criminal responsibility for trans homicide by categorizing that crime as one committed in the "heat of the moment" (see Steinberg 2005; Lee 2008). It has its origins in two other related kinds of legal argument: the homosexual (or, more recently, gay) panic defense and the nonviolent homosexual advance argument (Chen 2000; Steinberg 2005).

“Acute homosexual panic” was initially categorized as a psychiatric disorder in the 1920s, at a time when homosexuality was widely considered to be a mental disease. The term was used to characterize feelings of extreme anxiety ostensibly exhibited by latent homosexuals in same-sex situations, feelings that often led to self-harm or even suicide, though not normally to violence against others (Howe 1997; Golder 2004). According to Cynthia Lee, from 1967 onward, however, the idea of homosexual panic began to be used in support of "mental defect” defenses (such as insanity or diminished capacity) in the hope of mitigating the nature of the crime heterosexual men had committed in cases where they were charged with murdering gay men; the contention was that "the victim's (homo)sexual advance triggered in them [the heterosexual men] a violent psychotic reaction" causing them to lose control temporarily and to resort to lethal force (Lee 2008, 491, my emphasis).

Although in some of these cases, defense teams fell back on the idea of latent homosexuality to explain the "panic" experienced by the defendant, once homosexuality ceased to be categorized as a mental disorder in 1973, when the American Psychiatric 
Association removed it as a mental illness from its Diagnostic and Statistical Manual of Mental Disorders (DSM-II), they could no longer do so. At this point, however, the legal strategy of "homosexual" or "gay panic" did not disappear as one might have expected; it was reconceptualized as a form of provocation defense. $<7>$ Now it was asserted that "a nonviolent homosexual advance reasonably provoked them [the defendants] into a heat of passion” such that they killed (Lee 2008, 500; see also Chen 2000, 210). It is this latter version of the panic defense based on provocation that informs the trans panic strategy. Here it is allegedly the discovery that sexual intimacy has taken place (or is about to take place) with a trans person that is adjudged to prompt the ostensible "panic" that leads to violence. The legal basis of the provocation, however, is that the victim has withheld information about their "true" sex from their assailant. This is precisely the logic employed by the defense team in the Araujo case.

Keen to establish that their clients were guilty only of manslaughter, defense lawyers claimed first that there was no premeditation in the killing of Araujo, and second that there was no hate crime involved. In fact, commenting on the case afterwards, William Du Bois (Merel's lawyer at the second trial) claimed that his client "had a real affection" for Araujo, being “almost in love with her” (cited in Szymanski 2006b). "This crime didn’t occur because Mike had a bias,” Magidson's attorney Michael Thorman told the jury at the first trial. "It happened because of a discovery of what Eddie had done" (cited in Haddock 2004, my emphasis), “Eddie” being Araujo’s birth name. $<8>$

What was it, though, that "Eddie” is alleged to have "done”? As Merel's lawyer at the first trial, Jack Noonan, put it, "he” was guilty of "sexual deceit” (cited in St. John 2004b). In the words of Thorman, Araujo had "lied to get them [Merel and Magidson] to engage in sex with her" (cited in St. John 2005). His client, Noonan claimed, had "had sex with a person who he thought was somebody else” (cited in St. John 2004b); he had been duped. It was the 
discovery of this "deception” that provoked the emotional reactions-“anger and rage and shock and revulsion” in the case of Magidson (Thorman, cited in Hoge 2004); an intensely tearful, emotional breakdown in the case of Merel-that caused Araujo's brutal homicide. $<9>$ In short, as captured in the headline that appeared in The San Francisco Chronicle: “Teenager provoked own killing, attorney says” (St. John 2005).

Panic-style defenses have been explored by a number of legal scholars (Howe 1997; Chen 2000; Golder 2004; Steinberg 2005; McDonald 2006; Lee 2008; and Tilleman 2010), concerned above all with their efficacy or suitability as vindications for murder. My main interest is not, however, in the legal viability of the trans panic defense; it is in how this defense functions to (re)instate a particular world view through the classificatory system it uses to position the sexed body of the trans individual. As Lucinda Finley points out, the “concepts, categories, and terms that law uses” have "a particularly potent ability to shape popular and authoritative understanding of situations.” In this respect, legal language “reinforces certain world views and understandings of events” (Finley 1989, 888). With regard to the trans panic defense, the question is how does it function in support of a heteronormative understanding of transgender and trans murder? More specifically, how, in particular, does it operate as a mode of violence that parallels, though is distinct from, the lethal violence meted out by the killers of trans persons? In the next section, therefore, I set out what I mean by heteronormative violence before turning in the subsequent section to the question of how that violence was enacted at the trial of Araujo's killers.

\section{HETERONORMATIVE VIOLENCE}

Heteronormativity is a much-used though often ill-defined term. Originating in the work of queer theorist Michael Warner (Warner 1991; 1993), though clearly influenced by earlier feminist work on what has been variously called the "heterosexual contract" (Wittig), “compulsory heterosexuality” (Rich), or “obligatory heterosexuality” (Rubin; see Jackson 
2006), heteronormativity has "become widely used," as Stevi Jackson observes, "as shorthand for the numerous ways in which heterosexual privilege is woven into the fabric of social life, pervasively and insidiously ordering everyday existence” (Jackson 2006, 108; see also Berlant and Warner 1998). Although there is disagreement, as Samuel Chambers reports, about how best to characterize this privilege, with some construing it in terms of "practices," others as "rules," and still others as a "system of binary gender" (Chambers 2009, 65), it has been most commonly defined in terms of "norms," the approach I will follow. Thus, Robert Corber and Stephen Valocchi surmise, “[h]eteronormativity” refers to "the set of norms that make heterosexuality seem natural or right and that organize homosexuality as its binary opposite” (Corber and Valocchi 2003, 4). But what does it mean to say that "within social life heterosexuality is constructed as a compulsory norm” (Beasley 2005, 251)?

"Norm" may, of course, be used in a variety of different ways. The Oxford English Dictionary defines a norm, deriving from the Latin norma (meaning carpenter's square, pattern, rule), as a "standard, a type; what is expected or regarded as normal; customary behaviour, appearance.” Etymologically, “norm” links to “normal,” its adjectival form connoting "constituting or conforming to a type or standard; regular, usual, typical; ordinary, conventional. Also, physically or mentally sound, healthy" (as well as "heterosexual"); to “normalize,” a transitive verb meaning “to make normal or regular; cause to conform”; and to "normative," as in "establishing a norm or standard; of, deriving from, or implying a standard or norm; prescriptive.” In social theory, norms have variously been viewed as the glue holding the social order together, an external constraint on the individual, constitutive of the self and, by extension, constitutive also of social action (Jackson 2006, 109). By contrast, according to Michel Foucault, norms are to be understood as both disciplinary and productive. 
To contend that "heterosexuality is the norm, in culture, in society, in politics" (Chambers 2009, 35) might, therefore, be to make at least one of two claims: the first distributional, that statistically "heterosexuality" is the type of sexuality that occurs most frequently within the population; and the second normative, that heterosexuality is a prescribed mode of behavior, a regulatory standard, deviation from which is liable to censure, medical intervention, or worse. For the purposes of this paper, it is the latter conceptualization of norms that (as for Chambers, Beasley, et al.,) is most pertinent to my argument; norms that establish heterosexuality as the default position in society (Warner 1993; Berlant and Warner 1998; Chambers 2009), where to be human is to "be” heterosexual (Warner 1993, xxiii) and where "heterosexual experience is synonymous with human experience” (Yep 2002, 167).

It is often assumed that the concept of heterosexuality is "as old as procreation" (Katz 1995, 13). In fact it is of relatively recent historical origin. The term heterosexuality was, as Katz demonstrates, first used publicly in Germany in 1880, having been coined only some twelve years earlier in $1868(54,52)$, at which point it was differentiated from “'Normalsexualität,' normal sexuality” (52). At this time, 1868, Karl Maria Kertbeny (the originator of the term) saw heterosexuality and "normal sexuality," Katz notes, "as the innate form of sexual satisfaction of the majority of the population," with this stress on numbers as the basis of the "normal" signifying a "historical break with the old, qualitative, procreative standard" $(52,53)$ that preceded it. As late as the 1920s in the US, however, the label "heterosexual" was associated not with "normal sex, but with perversion," the hetero in heterosexual referring "not to their [the heterosexual's] interest in a different sex, but to their desire for two different sexes" (19-20, emphasis in original). A more thoroughgoing account of heteronormativity than that offered in this paper would thus need to acknowledge the historical conditions of possibility enabling the construction of heterosexuality as a norm in the sense that it operates today. $<10>$ 
As Sara Ahmed observes, heteronormativity refers to "more than simply the presumption that it is normal to be heterosexual," however historically specific that idea may be. "The 'norm,”” as she rightly notes, “is regulative” (Ahmed 2004, 149). Heteronormativity, I want to suggest, borrowing from Robyn Wiegman, is thus more accurately construed as both "the consequence as well as the sustaining force” (Wiegman 2006, 94) not just of norms of sexed anatomy that posit two (and only two) mutually exclusive but complementary kinds of bodies (one male, one female), most easily distinguishable by their different genitalia, but also, following Judith Butler, of norms of gender and sexuality (Butler 1990): specifically, the norms of binary gender that dictate that biological maleness naturally gives rise to masculinity and femaleness to femininity, and the norms of sexuality that construe heterosexuality as the outcome of "normal" psychological development and that ordain that heterosexual sex is "natural"-or, to put it another way, the norms that "naturalize" heterosexuality. $<11>$

As Butler and others have pointed out, such (hetero-)norms constitute both the bodies that conform to them as well as those that deviate from them (Butler 2004a, 42; see also Chambers 2007, 49 n. 17). This, of course, means that although as Corber and Valocchi remind us, phenomena such as intersex and transgender "provide graphic illustrations of the institutional and discursive power required to maintain the normative alignment of sex, gender, and sexuality” (Corber and Valocchi 2003, 9), heteronormativity also affects, though is not necessarily co-extensive with, heterosexuality. It conditions what it is acceptable to feel, who it is legitimate to be attracted to, and defines the kind of behavior attaching to heterosexual masculinity and femininity. In this sense, the impact of heteronormativity is both constitutive and regulatory.

What, though, is violent about heteronormativity understood in this way? Here I turn to Butler's work to explain. In the course of discussing Monique Wittig's work in Gender 
Trouble, Butler writes that (for Wittig) “'sex’ is the reality-effect of a violent process that is concealed” by its (re)presentation of sex as an "objective datum of experience” (Butler 1990, 114). In “Contingent Foundations" (Butler 1992), she elaborates further on what she understands by her earlier statement that categorization effects a "material and physical violence against the bodies” it claims merely to describe (Butler 1990, 116). She notes:

Consider that most material of concepts, "sex," which Monique Wittig calls a thoroughly political category, and which Michel Foucault calls a regulatory and “fictitious unity.” For both theorists, sex does not describe a prior materiality, but produces and regulates the intelligibility of the materiality of bodies. For both, and in different ways, the category of sex imposes a duality and a uniformity on bodies in order to maintain reproductive sexuality as a compulsory order. . . . I would like to suggest that this kind of categorization can be called a violent one, a forceful one, and that this discursive ordering and production of bodies in accord with the category of sex is itself a material violence. (17, my emphasis)

To talk of the categorization of bodies in terms of sex as "violent" may seem odd. Conventional approaches to violence usually conceive of it as "something done to bodies," entailing the "rupturing of the surface of the body, a wound" (Ross 2004, 2-4), "bruises, scratches, swellings . . . broken bones . . loss of body parts, or death” (Keane 2004, 35); it is a phenomenon, in other words, that equates to "physical aggression" (Richard Felson, cited in Ray 2011, 9): violence, that is, of the kind Araujo was subjected to so lethally by her killers. As Sally Engle Merry reminds us, however, "violence as an act of injury cannot be understood outside the social and cultural systems which give it meaning” (Merry 2009, n.p.). The ability to "see" certain acts or phenomena as violent-and/or as particular kinds of 
violence-is socially and politically contingent. Here it is only necessary to recall the feminist campaign that constructed nonconsensual sex within marriage as a form of gendered political violence.

Although in work on violence, it is common, even usual, to regard the body as existing prior to the violence it experiences, Butler, in calling on Wittig and Foucault, contends by contrast that the categorization of the sexed body is itself materially violent. It is this particular insight I want to pursue here.

Understanding sex as an effect is not, of course, new. "Sex," as Foucault recognized, cannot be conceived of "in itself" (Foucault 1978, 152); it is, rather, "an artificial unity, anatomical elements, biological functions, conducts, sensations, and pleasures” (154). The idea that classifying bodies in accordance with the norm of sexual dimorphism is a mode of violence, however, is perhaps more controversial. In “Contingent Foundations," Butler describes this process in Derridean terms as the "violence of the letter” (Derrida 1974; Butler 1992, 17), “writing," or language, that “is violent in so far as it classifies and categorizes” (Howells 1999, 53).<12> In later work, however, she refers to it as both "normative violence” (Butler 1999, xix-xx; see also Butler 2007; Chambers 2007; Jenkins 2007; Lloyd 2007; and Mills 2007) and to "gender norms ... as violations” (Butler 2004a, 214)

I am not concerned in this paper with the details of these terminological shifts. It is what Butler's different accounts share that is of interest: namely, the idea that there is violence in the way that bodies are constituted and regulated as sexed, whether that violence operates through language or discourse (as implied by the violence of the letter), through norms (as suggested by normative violence), or through some as yet other undisclosed means. I refer, in this paper, to this understanding of violence as "heteronormative violence" rather than the more generic "normative violence" as adopted by, for instance, Chambers or Mills (Chambers 2007; Mills 2007). I do so to signal the specificity of the violence I am concerned 
with here-namely the violence enacted in the ordering and classification of bodies according to the norms of sex, gender, and sexuality denoted above-rather than to generalize about "the inherent violence of norms” per se (Chambers 2007, 49 n. 17; see also Mills 2007) as they relate to all manner of phenomena. $<13>$

According to Butler, "sex" is not made once and for all but is rather "an ideal construct ... forcibly materialized through time” (Butler 1993, 2), the effect of an "iterable process" (Butler 2007, 182). Logically, therefore, the violence productive of binary sex must itself also be reiterative. These various violent (re)iterations or materializations, I suggest, take different forms. One takes place when trans individuals are violently assaulted for being trans: when, that is, (to echo Butler) the "violent enforcement of a category violently constructed" occurs and the body of the trans individual is "reduced" (through physical violence) to its biological “sex" (Butler 1990, 166 n. 26). Another mode of violent materialization occurs, as I show in the next section, at trial each time the lawyers involved position trans women such as Gwen Araujo as "male.”

\section{The Trans Panic Defense and/as Heteronormative Violence}

In positing the idea of trans panic as a legitimate excuse or justification for murder, the law is engaged in the articulation of norms that "universalize particular modes of living, and specific identities and acts” (Bower 1997, 267). The law’s relation to what Foucault calls “the things to be known," in this case the body of the trans individual, is one "of violence, domination, power, and force, a relation of violation” (Foucault 1994, 9). This violence is heteronormative in the case of the trans panic defense because the knowledge the law claims about the body of the victim is its "true sex," sex the law conceives of in binary terms. The assertions the law makes about binary morphology do not describe an objective truth about the sexed corpus, however; they forcibly constitute that body as "sexed." This is evident in 
the defense's interpretation of the significance of the discovery that Araujo had male genitalia.

Although Araujo lived as a woman and so did not, in fact, misrepresent her gender to her killers, because her gender was feminine, in terms of sexed intelligibility she was immediately recuperated by the defense as "male" (see also Tilleman 2010, 1679). Indeed, the charge of deception used to ground cases of provocation in trans homicides rests on this very assumption: that the victim has hidden knowledge of her/his "real" sex from her/his assailants and has, thus, deceived them. $<14>$ Instead of recognizing Araujo's own selfdesignation as a woman, lawyers in the two trials appropriated to themselves the authority to determine both Araujo’s gender and sexed identity (Mackenzie and Marcel 2009). They did so by reiterating a heteronormative understanding of the body and of the "normal" relation assumed to obtain between anatomical sex and gender-namely, where genital sex is taken to be determinative of gender. Since Araujo had male sex organs, according to this logic, it could only mean that no matter how convincing her performance of femininity, she was really a man "pretending” to be a woman.

At issue in trans murder trials, however, is not just the relation between sex and gender. Since, according to the logic of heteronormativity, Araujo lacked the "biological credentials" (Schilt and Westbrook 2009, 456) that would confirm her sexual orientation as heterosexual (namely, a vagina), her sexuality was also put in question. Since she was "really" a "he" who had sex with men, then as far as the defendants and their lawyers were concerned, "Eddie" must be gay. $<15>$ The exposure of Araujo's genitalia was seen as provocative not only because it revealed that she was male but, additionally, because it led her killers to "understand" the sexual relations they had engaged in with her as acts of homosexual sex, not the heterosexual sex they had believed them to be. The trans panic defense thus reveals what Andrew Sharpe refers to as "the legal anxiety over homosexuality" that appears when the 
parties to sexual relations share similar genitals, an anxiety heightened when both of those parties "assert heterosexual identity and desire” (Sharpe 2006, 628), as in the case under examination.

This anxiety is discernible in the stress placed on the impact the discovery of Araujo's “genital topography” (Sharpe 2006, 623) allegedly had on the defendants. Lawyers deployed testimony both from and about Merel that drew attention to the fact that he "threw up, disgusted that he had had sexual relations with a man"; became agitated at the thought that he might be gay "based on his belief that it was impossible for a heterosexual man to receive sexual pleasure from another man” (People v. Merel 2009); and that, as he attacked Araujo, he repeated over and over the "sobbing mantra: 'I can’t be . . gay”” (Haddock 2004; Lee 2004; Steinberg 2005, 520; and People v. Merel 2009).

Steinberg also recounts how another of the defendants spoke about how "his illusion as to normality and the way things are supposed to be had been shattered” (Steinberg 2005, 520) when he learned Araujo was anatomically male. It was this that led Thorman to describe "what Eddie had done" (to recall his phrase) as a "theft of heterosexuality" (Szymanski 2006b). As he told the jury in closing arguments: "Sexuality, our sexual choices, are very important to us. They're private, they're personal . . . and for young men, they form a substantial part of their identity. . . . That's why the deception in this case was such a substantial provocation—sexual fraud, a deception, a betrayal” (Thorman, cited in St. John 2004b)_-because Araujo had enticed Merel and Magidson unknowingly into homosexual sex with "him," the disclosure of which tipped them over the edge into violence.

The trans panic defense as articulated at the trial of Araujo's killers, and echoed in other parallel trials, enacts the violence that is heteronormativity in a number of different ways: in its assertion of binary sex, the "fact" of which, as Allen notes, is "taken as a fundamental a priori of legal reasoning” (cited in Howe 1997); in its (re)production of heterosexuality as the 
coupling of one anatomically male with one anatomically female body; when it posits the heterosexual male as a "real" man who prefers "real" women; and when it presents heterosexual masculinity as sexually predatory by nature but never sexually vulnerable (Lee 2008, 488). It does so, too, when it takes heterosexuality to be the "presumptive standard" (Chen 2000, 209) of reasonableness. $<16>$ Heteronormative violence is further performed through the suggestion that the trans woman's body, the materiality of her sex, is provocation enough in itself to bring about her own demise: when it assumes that the corpus provides a sufficient reason—a "sexed" reason, as Butler might put it—for murder. It is manifest, finally, in the attempt to "disavow[. . .]" the violence the transwoman suffers, as Fiona Jenkins writes in a different context, "in the name of a right to destroy that which threatens one’s very existence” (Jenkins 2007, 166). When lawyers contend that lethal violence "should be expected or excused if it is committed in response to the discovery of a partner's transgender status” (Szymanski 2005, my emphasis), and when they claim, as Thorman did, that the "right" of "a heterosexual male . . . to make choices for his life, and . . . to choose the gender of his partners" trumps that of the victim "to be who she thinks she is" (cited in St. John 2004a), it is clearly normative heterosexuality that is being protected.

The trans panic defense draws (some of) its heteronormative "force" from its reiteration of the commonly held idea that there exists a natural sexual dimorphism, an idea that organizes its legal logic. But this forceful reiteration is also, and crucially, the means by which the trans panic defense itself operates forcibly to "sex" the bodies of trans individuals and to discipline and regulate them according to the gender norms productive of presumptive heterosexuality. $<17>$ By actively "sexing” Araujo as male and by presenting her as a gender fraud, the defense team denied Araujo's own gender identification as feminine and, consequently, categorized the sexual relations she had with men as straightforwardly homosexual ones rather than as complexly heterosexual. $<18>$ 


\section{THE ViOLENCE THAT Is HETERONORMATIVITY}

My aim in this paper has been to explore heteronormative violence. This violence, I have argued, operates through a range of different modalities, two of which I have examined in this paper: the physical violence inflicted on Araujo’s body by her murderers - the beating that killed her-and the violence of “categorization” (to borrow Butler's description) that inheres in the trans panic defense. Both are modes of heteronormative violence in that both reduce Araujo's body to its "sex"; both, that is, produce it as male, though each does so in a different way: one through sickening brutality, the other discursively, through a carefully crafted legal defense strategy. Heteronormative violence, in this case, I have suggested, was forcibly enacted through the circulation of a series of norms or purported "facts" of sex, foremost among which were the twin norms that bodies are sexually dimorphic, revealed by the presence or absence of particular genitalia, and that it is possible to read sexual orientation off that genitalia. In other words, that "heterosexual" desire is tied to body morphology (that a person with a vagina desires a person with a penis) rather than to gender identity (that someone feminine desires someone masculine).

Even though the trans panic defense failed on this occasion, what it reveals as a legal strategy, nevertheless, are some of the ways that heteronormativity, in general, is maintained and further entrenched: through the continuous and never-ending reiteration of the normative category of sex (and its associated notions of gender and desire), and through the insistent materialization of bodies according to those norms. These forcibly reiterated processes may not always be immediately visible, but this is only because the category of biological sex has become naturalized, treated, that is, as an incontrovertible "fact" of all bodies, a fact that the law, as noted earlier, has assumed as part of its very logic. In reality, the constant and unrelenting violent (re-)production of bodies as sexed operates to uphold the norm of compulsory heterosexuality that requires this binary designation of the sexes in the first 
place. Furthermore, it is the constant circulation of these very norms, whether imposed on bodies involuntarily (as when babies are "sexed” at birth) or actively taken on by individuals when they assert a particular sexed identity as male or female, that both makes heteronormativity possible and that sustains its violating operations.

To understand and then challenge the violence that is heteronormativity, in particular heteronormativity's dependence on a continuous enactment of violence, it is vital for political and analytical reasons to attend to the multiple, sometimes contradictory, ways that violence is performed. In addition to the kind of scrutiny offered in this paper of the violence of both trans murder and the trans panic defense, this includes examining the materially specific forms of violence enacted in, for instance, the treatment of intersex (the use of "corrective surgery" to forcibly transform a nonnormative body into a normative one). Heteronormative violence is not just a problem of/for nonnormative sexes, gender, and sexualities, though; it structures heterosexuality. Attention thus needs to be paid too to its operations in constructing, governing, and policing heterosexual desire: the many ways, for instance, that heterosexuality is violently institutionalized in law, culture, or social policy. Indeed, it is only by investigating the diverse modalities of violence through which it operates that it is possible to fully appreciate the reach and the persistence of heteronormativity, including its capacity to sustain a belief in the existence of two and only two sexes and, no matter how much it has been challenged politically, the view that gender follows from sex.

\section{NOTES}

1. Since Araujo conceived of and presented herself as a woman, I will also refer to her by either her feminine name, Gwen, or by the feminine pronoun, except when quoting directly from other sources. 
2. For example, the defense succeeded at the 1997 trial in Boston of William Palmer, who beat, strangled, and suffocated to death trans woman Chanelle Pickett. Palmer was acquitted of both first- and second-degree murder at his trial, and of manslaughter. He received a twoyear sentence for assault and battery (Haddock 2004; Steinberg 2005, 521; Tilleman 2010, 1671). The same defense was also used in 2004 when Estanislao Martinez was sentenced to four years in prison for stabbing trans woman Joel Robles more than twenty times with a pair of scissors and killing her (Bettcher 2006, 183). A plea of "voluntary manslaughter” was accepted by the District Attorney in this case because the "prosecutor did not believe he could get a jury to convict for murder in that case” (Jennifer Muir, cited in Brigham 2006).

3. For instance, San Francisco District Attorney Kamala Harris convened a symposium on the "panic defense" that included a panel entitled "The Araujo Trial: A Case Study," featuring members of the defense team as well as Chris Lamiero, the lead prosecutor in the case (Szymanski 2006a). Furthermore, on September 28, 2006 the Gwen Araujo Justice for Victims Act (AB 1160) was signed into California state law by its then Governor, Arnold Schwarzenegger. This act, inspired by the killing of both Araujo and Robles, limits the use of ““panic strategies’ to influence the proceedings of a criminal trial” (Lieber n.d.).

4. The term archive is Judith Halberstam's (Halberstam 2005, 23). The Araujo archive includes academic writing, legal documents, a film, and press reports. According to MacKenzie and Marcel, 16,685 words were published by the press about this case in the first seven days after Araujo's murder compared to just 5,400 words for Pickett's murder for the same timeframe; this rose to over 392,000 published words between 2002-April 2008 (MacKenzie and Marcel 2009, 103 n. 29).

5. As several commentators have noted, there is a problem with conceiving of attitudes toward nonnormative sexual minorities as individual phobias (Wickberg 2000, 45; Chambers 2009, 34) because doing so occludes the political, cultural, social, and legal arrangements 
(institutional, organizational, and ideological) that normalize heterosexuality and conceive of nonheterosexual modes of being, doing, or acting as nonnormative.

6. The jurors split 10-2 in favor of acquitting Merel and Cazares, and 7-5 in favor of convicting Magidson (DeFao and St. John 2004).

7. In legal terms, a shift took place from the homosexual panic defense (HPD) to the homosexual advance defense (HAD).

8. Using a transgender person's birth name rather than his or her preferred name, as MacKenzie and Marcel suggest, is a way “to undermine the transwoman's transgender identity, rather than representing her as a person with a legitimate gender and body" (MacKenzie and Marcel 2009, 83).

9. At the preliminary hearing at the trial of Allen Andrade, who murdered trans woman Angie Zapata, his lawyer defended him by arguing that: "At best, this is a case about passion," continuing, "When (Zapata) smiled at him, this was a highly provoking act, and it would cause someone to have an aggressive reaction” (Annette Kundelius, cited in Whaley 2008). In this case, the Colorado jury took two hours to convict Andrade of first-degree murder, with a three-year hate crime enhancement added to his conviction (Tilleman 2010, 1662).

10. Heteronormativity is perhaps best understood as functioning as a dispositif in Foucault's sense of the word: that is, as a complex ensemble of relations between (among other heterogeneous phenomena) discourses, institutions, laws, regulations, scientific propositions, and common sense beliefs that emerges at a particular historical moment in response to some kind of "urgent need" (Foucault 1980, 195).

11. For critical discussions of heterosexuality, see Richardson 1996; Jackson 1999; Ingraham 2005. For a critique of the relationship between heterosexuality and heteronormativity, see Jackson 2006. 
12. Chambers provides an interesting discussion of the parallels between Derrida's and Butler's accounts of violence, though oddly he does not examine Butler's own discussion of the "violence of the letter" (Chambers 2007).

13. Although much of Chambers's actual discussion is on the link between "normative violence" and heteronormativity, his aim is to develop normative violence as a political concept that might be of interest to political theorists more generally (Chambers 2007, $49 \mathrm{n}$. 17). In discussing normative violence, however, Butler appears to argue against generalizing the concept too far (and, in particular, against assuming that "all normativity is founded in violence” [Butler 2007, 184]). I too want to reject the claim that norms or normativity per se are either necessarily or always violent. In this way I also keep my distance from those queer accounts of heteronormativity that apparently pathologize normativity as such (for further discussion of this point, see Wiegman 2006).

14. A similar charge of deception was laid against the victim in the Andrade trial (Hernandez 2009). As Andrade’s lawyer told potential jurors at jury selection, “Angie was in fact Justin” (Kundelius, cited in Tilleman 2010, 1661). See Bettcher 2006, Bettcher 2007, and Schilt and Westbrook 2009 for articles exploring the association of transgender with gender deception.

15. Perversely, gay and lesbian activism may have done its work too well in this regard, in cementing the idea that same-sex desire essentially defines someone as homosexual.

16. Critics have argued that the standards of reasonableness operating in the US courts not only "reflect a male view of understandable homicidal violence" (Chen 2000, 195) but are predicated upon presumptive heterosexuality insofar as the courts have refused to postulate an alternative standard of "reasonableness" for male homosexuals or for women (straight or gay). 
17. We could, in fact, go further and suggest that the logic of the trans panic defense also performs its violence against the defendants. Far from shoring up their heterosexuality, which had supposedly been threatened by the sexual encounters with Araujo, it actually destabilizes

it, for if, according to its heteronormative logic, being a man is indicated by the presence of a penis and being gay by having a penis and having sex with men, then, by implication, the defendants must also be gay. I am grateful to one of the anonymous referees for Hypatia for prompting me to consider this inconsistency in the defense's logic, though I do not have the space here to pursue its implications any further.

18. In fact, the prosecutor in this case, Chris Lamiero, doubting he could convince the twelve jurors to "agree that Araujo was a woman" (Szymanski 2005), built his prosecution case on "the conduct of the defendants, not on the conduct of Gwen" (cited in Szymanski 2006b).

\section{REFERENCES}

Ahmed, Sara. 2004. The cultural politics of emotion. Edinburgh, UK: Edinburgh University Press.

Baldman, Anthony. 2006. Bill aims to eliminate gay/trans panic strategies in criminal trials. Gay and Lesbian Times, January 19.

Balzer, Carsten. 2009. Every third day the murder of a trans person is reported. Liminalis: Journal for Sex/Gender Emancipation and Resistance 3: 147-59.

Beasley, Chris. 2005. Gender and sexuality: Critical theories, critical thinkers. London: Sage.

Berlant, Lauren, and Michael Warner. 1998. Sex in public. Critical Inquiry 24 (2): 547-66. 
Bettcher, Talia Mae. 2006. Appearance, reality and gender deception: Reflections on transphobic violence and the politics of pretence. In Violence, victims, justifications: Philosophical approaches, ed. Felix Ó Murchadha. Oxford: Peter Lang.

_ 2007. Evil deceivers and make-believers: On transphobic violence and the politics of illusion. Hypatia 22 (3): 43-65.

Bower, L. 1997. Queer problems/straight solutions: The limits of “official recognition.” In Playing with Fire, ed. Shane Phelan. London: Routledge.

Brigham, Roger. 2006. TG panic bill weakened. The Bay Area Reporter, 24 April.

Butler, Judith. 1990. Gender trouble: Feminism and the subversion of identity. London: Routledge.

1992. Contingent foundations. In Feminists theorize the political, ed. Judith Butler and Joan Scott. London: Routledge.

1993. Bodies that matter: On the discursive limits of "sex”. London: Routledge.

. 1999. Gender trouble: Feminism and the subversion of identity. Tenth anniversary edition. London: Routledge.

—. 2004a. Undoing gender. London: Routledge.

—. 2004b. Precarious life: The powers of mourning and violence. London: Verso.

—. 2007. Reply from Judith Butler to Mills and Jenkins. Differences: A Journal of Feminist Cultural Studies 18 (2): 180-95.

Chambers, Samuel A. 2007. Normative violence after 9/11: Rereading the politics of Gender Trouble. New Political Science 29 (1): 43-60.

- 2009. The queer politics of television. London: I. B. Taurus.

Chen, Christina Pei-Lin. 2000. Provocation’s privileged desire: The provocation doctrine, "homosexual panic," and the non-violent unwanted sexual advance defense. Cornell Journal of Law and Public Policy 10: 195-235. 
Corber, Robert J., and Stephen Valocchi, eds. 2003. Queer studies: An interdisciplinary reader. Oxford: Blackwell Publishing.

DeFao, Janine, and Kelly St. John. 2004. Retrial in Araujo case presents challenges. San Francisco Chronicle, June 28.

Derrida, Jacques. 1974. Of grammatology. Baltimore: Johns Hopkins University Press.

Finley, Lucinda M. 1989. Breaking women's silence in law: The dilemma of the gendered nature of legal reasoning. Notre Dame Law Review 64: 886-910.

Foucault, Michel.1978. History of sexuality. Volume 1. Harmondsworth, UK: Penguin.

- 1994 Truth and juridical forms. In Michel Foucault: Power. Essential works of Foucault 1954-1984, vol. 3, ed. James D. Faubion. London: Penguin.

Golder, Ben. 2004. The homosexual advance defence and the law/body nexus: Towards a poetics of law reform. Murdoch University Electronic Journal of Law. http://papers.ssrn.com/sol3/papers.cfm?abstract_id=1351564 (accessed September 25, 2012).

Haddock, Vicki. 2004. “Gay panic” defense in Araujo case. San Francisco Chronicle, May 16.

Halberstam, Judith. 2005 In a queer time and place: Transgender bodies, subcultural lives. New York: New York University Press.

Hernandez, Lance. 2009. Wednesday: Closing arguments. Andrade murder trial blog. http://www.thedenverchannel.com/news/19250576/detail.html (accessed November 5, 2011).

Hoge, Patrick. 2004. Defense calls transgender victim guilty of “deception and betrayal.” San Francisco Chronicle, April 16. 
Howe, Adrian. 1997. More folk provoke their own demise (homophobic violence and sexed excuses-rejoining the provocation law debate, courtesy of the homosexual advance defence. Sydney Law Review 19 (3): 335-65.

Howells, Christina. 1999. Derrida: Deconstruction from phenomenology to ethics. Cambridge, UK: Polity.

Human Rights Commission. 2011. How do transgender people suffer from discrimination? http://2fwww.hrc.org/issues/1508.htm (accessed November 25, 2011).

Ingraham, Chrys, ed. 2005. Thinking straight: The power, the promise, and the paradox of heterosexuality. London: Routledge.

Jackson, Stevi. 1999. Heterosexuality in question. London: Sage.

—. 2006. Gender, sexuality and heterosexuality: The complexity (and limits) of heteronormativity. Feminist Theory 7 (1): 105-21.

Jenkins, Fiona. 2007. Toward a nonviolent ethics: Response to Catherine Mills. Differences: A Journal of Feminist Cultural Studies 18 (2): 157-79.

Katz 1995. The invention of heterosexuality. Chicago: University of Chicago Press.

Keane, John. 2004. Violence and democracy. Cambridge, UK: Cambridge University Press.

Lee, Cynthia. 2008. The gay panic defense. University of California, Davis, Law Review 42: 471-566.

Lee, Henry. 2004. Araujo begged for mercy. San Francisco Chronicle, April 27.

Lieber, Sally. n.d. AB1160 fact sheet: The Gwen Araujo Justice for Victims Act. Equality California.

Lloyd, Moya. 2007. Judith Butler: From norms to politics. Cambridge, UK: Polity.

MacKenzie, Gordene, and Mary Marcel. 2009. Media coverage of the murder of U.S. transwomen of color. In Local violence, global media: Feminist analyses of gendered representations, ed. Lisa M. Cuklanz and Sujata Moorti. New York: Peter Lang. 
McDonald, Elisabeth. 2006. No straight answer: Homophobia as both an aggravating and mitigating factor in New Zealand homicide cases. Victoria University of Wellington Law Review 37: 223-48.

Merry, Sally Engle 2009. Gender violence: a cultural perspective. Oxford: Wiley-Blackwell. Kindle edition.

Mills, Catherine. 2007. Normative violence, vulnerability, and responsibility. Differences: A Journal of Feminist Cultural Studies 18 (2): 133-56.

Organization for Security and Cooperation in Europe (OSCE). 2007. Hate crimes in the OSCE region: Incidents and responses. Annual report for 2006. Warsaw: OSCE.

People v. Merel, Cal: Court of Appeal, 1st Appellate Dist., 4th Div. 2009. http://scholar.google.co.uk/scholar_case?case $=7219233048697743719 \& h l=e n \& a s \_s$

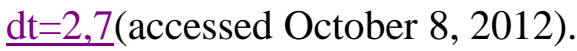

Ray, Larry. 2011. Violence and society. London: Sage.

Richardson, Diane, ed. 1996. Theorising heterosexuality. Maidenhead, UK: Open University Press.

Ross, Daniel. 2004. Violent democracy. Cambridge, UK: Cambridge University Press.

Schilt, Kristen, and Laurel Westbrook. 2009. Doing gender, doing heteronormativity: “Gender normals," transgender people, and the social maintenance of heterosexuality. Gender and Society 23 (4): 440-64.

Sharpe, Andrew. 2006. From functionality to aesthetics: The architecture of transgender jurisprudence. In The Transgender Studies Reader, ed. Susan Stryker and Stephen Whittle. New York: Routledge.

St. John, Kelly. 2004a. Nature of killing focus at end of Araujo case: Was transgender teen slain in heat of passion or revenge? San Francisco Chronicle, June 1. 
2004b. Defense in Araujo trial gives final argument. San Francisco Chronicle, June

3.

2005. Teenager provoked own killing, attorney says. San Francisco Chronicle,

August 30 .

St. Pierre, Ethan. 2011. Statistics and other info. http://www.transgenderdor.org/?page_id=192 (accessed July 17, 2011).

Steinberg, Victoria L. 2005. A heat of passion offense: Emotions and bias in "trans panic" mitigation claims. Boston College Third World Law Review 25: 499-524.

Szymanski, Zak. 2005. Two murder convictions in Araujo case. Bay Area Reporter, September 15.

- 2006a. Harris announces "panic defense" conference. http://www.law.ucla.edu/williamsinstitute/press/HarrisAnnoucesPanicDefenseConference (accessed November 16, 2009).

2006b. DA convenes "panic" conference. http://www.law.ucla/williamsinstitute/press/DAConvenesPanicConference.html (accessed November 17, 2009).

Tilleman, Morgan. 2010. (Trans)forming the provocation defense. Journal of Criminal Law and Criminology 100 (4): 1659-88.

Warner, Michael. 1991. Introduction: Fear of a queer planet. Social Text 29: 3-17.

Warner, Michael, ed. 1993. Fear of a queer planet: Queer politics and social theory. Minneapolis: University of Minnesota Press.

Whaley, Monte. 2008. Smile called "provoking act" in transgender case. Denver Post, September 19.

Wickberg, Daniel. 2000. Homophobia: On the cultural history of an idea. Critical Inquiry 27 (1): 42-57. 
Wiegman, Robyn. 2006. Heteronormativity and the desire for gender. Feminist Theory 7 (1): 89-103.

Yep, Gust A. 2002. From homophobia and heterosexism to heteronormativity. Journal of Lesbian Studies 6 (3-4): 163-76. 